\title{
Implementasi SAK EMKM Sebagai Dasar Penyusunan Laporan Keuangan Usaha Mikro Kecil dan Menengah (UMKM)
}

\author{
Ari Nuvitasari ${ }^{1 *}$, Norita Citra Y2, Nina Martiana ${ }^{3}$ \\ 1,2,3Program Studi Akuntansi Fakultas Ekonomi dan Bisnis, Universitas Muhammadiyah Jember,Indonesia
}

\author{
A R T I C L E I N F O \\ Article history: \\ Received 20 May 2019 \\ Received in revised form \\ 16 June 2019 \\ Accepted 20 July 2019 \\ Available online 30 August \\ 2019 \\ Kata Kunci: \\ UMKM, SAK EMKM, \\ Laporan Keuangan UMKM \\ Keywords: \\ UMKM, SAK EMKM, UMKM \\ Financial Report
}

\begin{abstract}
A B S T R A K
Perkembangan bisnis di Indonesia saat ini berkembang pesat. Salah satu jenis bisnis yang saat ini berkembang di Indonesia adalah Usaha Mikro, Kecil, dan Menengah (UMKM). UMKM adalah salah satu pendorong perekonomian bangsa dan memiliki peran penting dalam perekonomian di Indonesia karena dapat mendorong dan meningkatkan perekonomian secara berkelanjutan dan berkelanjutan. SAK UMKM adalah dasar untuk menyusun laporan keuangan menggunakan data primer. Dari hasil penelitian yang dilakukan di UD.Karya Tangi Banyuwangi, terlihat bahwa laporan keuangan yang disusun dan disajikan oleh UD.Karya Tangi Banyuwangi masih sangat sederhana dan tidak sesuai dengan SAK EMKM karena pemilik UMKM tidak memahami dan memahami standar laporan keuangan khusus untuk UMKM, setelah menerapkan laporan keuangan UD.Karya Tangi Banyuwangi berdasarkan SAK EMKM secara keseluruhan, disiapkan dan disajikan dengan jumlah yang sama. Penerapan laporan keuangan yang sesuai dengan SAK EMKM menyajikan laporan keuangan yang terdiri dari tiga komponen, yaitu laporan posisi keuangan, beberapa statistik dan catatan laporan keuangan.
\end{abstract}

A B S T R A C T

The development of business in Indonesia is currently growing rapidly. One type of business that is currently developing in Indonesia is Micro, Small, and Medium Enterprises (MSME). UMKM is one of the drivers of the nation's economy and has an important role in the economy in Indonesia because it can encourage and improve the economy sustainably and continuously. SAK UMKM is the basis for compiling financial statement using primary data. From the results of research conducted at UD.Karya Tangi Banyuwangi, it is shown that the financial statements prepared and presented by UD.Karya Tangi Banyuwangi are still very simple and not in accordance with SAK EMKM is because UMKM owners do not understand and understand the standard financial statements specifically for MSMEs, after implementing the financial statements of UD.Karya Tangi Banyuwangi based on SAK EMKM as a whole, prepared and presented with a number of the same. The implementation of financial statements that are in accordance with the SAK EMKM presents financial statements that consist ofithree components, inamely the statement of financial position,iincome statemen and notes toifinancial statement.

\footnotetext{
* Corresponding author.

E-mail addresses: arinuvi456@gmail.com (Ari Nuvitasari1)
} 


\section{Pendahuluan}

Kegiatan kewirausahaan yang dijalankan oleh EMKM (Entitas Mikro, Kecil, dan Menengah) dapat menciptakan lapangan pekerjaan bagi masyarakat. Namun, hal yang menjadi kendala EMKM adalah belum banyak EMKM yang mampu menyelenggarakan pencatatan, pembukuan bahkan pelaporan keuangan. Padahal penyelenggaraan pencatatan, pembukuan dan pelaporan keuangan adalah hal penting yang perlu dilakukan oleh setiap entitas, agar entitas dapat mengevaluasi kinerja entitas setiap tahunnya. Selain itu, entitas juga dapat menambah modal kerja usahanya dari pinjaman pihak perbankan dengan melampirkan laporan keuangan entitas (Nina, 2018).

Setiap usaha diharapkan mempunyai laporan keuangan untuk menganalisis kinerja keuangan sehingga dapat memberikan informasi tentang posisi keuangan, kinerja, dan arus kas yang bermanfaat bagi pengguna laporan keuangan dalam rangka membuat keputusan-keputusan ekonomi serta menunjukkan pertanggungjawaban manajemen atas penggunaan sumber daya yang dipercayakan kepada mereka. Namun praktek akuntansi keuangan pada UMKM masih rendah dan memiliki banyak kelemahan (Suhairi : 2004). Penelitian yang dilakukan Salmiah et.al (2015) dengan judul penerapan akuntansi pada UMKM Binaan Dinas Koperasi dan UMKM Kota Pekanbaru dan kesesuaiannya dengan SAK ETAP menemukan bahwa 83\% UMKM tidak memahami isi SAK ETAP, 70\% responden tidak menggunakan software akuntansi untuk menghasilkan informasi akuntansi yang tepat waktu dan relevan, dan $70 \%$ responden sebagai pelaku UMKM tidak memberikan informasi tambahan yang tidak disajikan dalam laporan keuangan sehingga informasinya tidak lengkap. Hal ini terjadi karena minimnya pengetahuan, pemahaman serta kesadaran akan pentingnya penerapan akuntansi secara lengkap dan sesuai dengan SAK ETAP bagi pelaku UMKM terutama dalam proses penyusunan laporan keuangan dalam rangka memperoleh informasi tentang kegiatan usaha selama satu periode akuntansi.

Penelitian yang dilakukan Saragih dan Surikayanti (2015) dengan judul Analisis penerapan akuntansi dan kesesuaiannya dengan SAK ETAP pada UKM Medan Perjuangan menemukan bahwa (1) penerapan akuntansi dilihat dari penyajian pelaporan keuangan pada UKM tersebut masih sederhana yaitu dengan melakukan pencatatan atas transaksi yang sering terjadi dalam usahanya. Sebagian besar UKM hanya membuat laporan laba-rugi. (2) Penerapan akuntansi yang dilakukan UKM di Jalan Seram, kecamatan Medan Perjuangan belum sesuai dengan SAK ETAP. Hal tersebut karena kurangnya pengetahuan mereka mengenai SAK ETAP serta tidak adanya Sosialisasi ataupun pelatihan dari pihak pemerintah maupun lembaga yang membawahi UKM masih kurang maksimal, sehingga pemahaman akan pentingnya SAK ETAP masih belum dipahami pelaku UKM Seiring perkembangannya, terdapat kebutuhan mengenai ketersediaan standar akuntansi yang lebih sederhana dari SAK Umum berbasis IFRS dan SAK ETAP bagi UMKM dikarenakan keterbatasan sumber daya manusia dalam menghasilkan laporan keuangan menggunakan kedua pilar SAK tersebut.

Karena itu, DSAK IAI melakukan pengembangan standar akuntansi yang dapat memenuhi kebutuhan UMKM dengan menghadirkan SAK yang dapat mendukung kemajuan UMKM di Indonesia. Hingga pada akhirnya pada tahun 2016, DSAK IAI mengesahkan Standar Akuntansi Keuangan Entitas Mikro, Kecil, dan Menengah (SAK EMKM) yang berlaku efektif pada tanggal 1 Januari 2018 sebagai upaya mendukung kemajuan perekonomian Indonesia. SAK EMKM memuat pengaturan akuntansi yang lebih sederhana dari SAK ETAP. Dengan adanya SAK EMKM maka diharapkan UMKM lebih maju dan mandiri misalnya UMKM dapat menyeleggarakan pencatatan atas laporan keuangan usahanya. Mengingat informasi akuntansi mempunyai peranan penting untuk mencapai keberhasilan usaha, termasuk bagi UMKM. Informasi akuntansi dapat menjadi dasar yang andal untuk memperoleh kredit dari bank, tujuan pelaporan pajak maupun tujuan internal perusahaan seperti pengambilan keputusan ekonomis dalam pengelolaan usaha, antara lain keputusan pengembangan pasar, penetapan harga dan lain-lain. Dengan demikian diharapkan dengan adanya SAK EMKM akan meningkatkan profesionalitas dari UMKM.

Dengan adanya SAK EMKM, maka UMKM tidak perlu membuat laporan keuangan dengan menggunakan SAK umum berbasis IFRS dan SAK ETAP. Di dalam beberapa hal SAK EMKM memberikan banyak kemudahan bagi UMKM karena SAK EMKM memuat pengaturan akuntansi yang lebih sederhana dibandingkan dengan SAK ETAP. Walaupun SAK EMKM dinyatakan lebih sederhana dan lebih mudah penerapannya dibandingkan dengan SAK Umum berbasis IFRS dan SAK ETAP, tidaklah semudah yang dikatakan karena untuk menerapkan SAK EMKM dalam proses pelaporan keuangan tentunya memerlukan pemahaman yang cukup bagi pelaku UMKM namun di sisi lain Suhairi (2004) menyatakan bahwa kesadaran UMKM dalam melaksanakan praktik keuangan masih rendah dan memiliki banyak kendala dan kelemahan yang disebabkan tingkat pendidikan yang rendah dan kualitas sumber daya manuasia yang kurang memadai. Disamping itu, SAK EMKM yang dianggap lebih mudah tapi relatif baru bagi entitas bisnis maupun pemerintah dan pihak lainnya. Suksesnya implementasi SAK EMKM secara keseluruhan adalah sebuah perjalanan panjang yang membutuhkan kesiapan dari pelaku UMKM. Untuk 
itu penelitian tentang pemahamanan SAK EMKM bagi pelaku UMKM ini sangat perlu untuk dilakukan (Salmiah, 2018).

Perkembangan bisnis di Indonesia saat ini semakin pesat. Salah satu jenis usaha yang kini sedang berkembang di Indonesia adalah Usaha Mikkro Kecil dan Menengah (UMKM). UMKM merupakan salah satu penggerak perekonomian bangsa dan memiliki peran penting dalam perekonomian di Indonesia karena dapat mendorong serta meningkatkan perekonomian secara berkesinambungan dan terus menerus. UMKM diharapkan dapat mengusai pangsa pasar nasional maupun pasar internasional, dengan menyediakan produk-produk yang berkualitas dan terpercaya agar mampu memajukan dan menambah perekonomian negara serta juga dapat mengurangi tingkat pengangguran saat ini. Usaha Mikro Kecil dan Menengah (UMKM) adalah suatu bentuk usaha yang didirikan oleh perorangan atau kelompok yang dilihat dari skala usaha rumahan dan usaha kecil yang hanya mempunyai jumlah karyawan antara 1-19 orang. Sementara usaha menengah mempunyai pegawai antara 20-99 orang (BPS, 2004). Usaha kecil dan menengah adalah jenis usaha yang memiliki jumlah pegawai paling banyak di Indonesia, akan tetapi saat ini masih banyak yang menjadi batasan mengenai kriteria usaha kecil yang masih beragam. Pengertian UMKM juga masih relatif kurang dan banyak yang belum mengetahui. Sehingga diperlukan adanya batasan untuk menimbulkan definisi-definisi dari berbagai segi yang menciptakan suatu UMKM (Hutagaol, 2011).

Keberadaan UMKM tidak dapat dihapuskan ataupun dihindarkan dari masyarakat bangsa saat ini. Karena keberadaannya sangat bermanfaat dalam hal pendistribusian pendapatan masyarakat. Selain itu juga mampu menciptakan kreatifitas yang sejalan dengan usaha untuk mempertahankan dan mengembangkan unsur-unsur tradisi dan kebudayaan masyarakat setempat. Pada sisi lain, UMKM mampu menyerap tenaga kerja dalam skala yang besar mengingat jumlah penduduk Indonesia yang besar sehingga hal ini dapat mengurangi tingkat pengangguran. Dari sinilah terlihat bahwa keberadaan UMKM yang bersifat padat karya, menggunakan teknologi yang sederhana dan mudah dipahami mampu menjadi sebuah wadah bagi masyarakat untuk bekerja (www. smecda.com). Program pengembangan Usaha Mikro, Kecil, dan Menengah (UMKM) sebagai salah satu instrument untuk menaikkan daya beli masyarakat, pada akhirnya akan menjadi katup pengaman dari situasi krisis moneter. Pengembangan UMKM menjadi sangat strategis dalam menggerakkan perekonomian nasional, mengingat kegiatan usahanya mencakup hampir semua lapangan usaha sehingga kontribusi UMKM menjadi sangat besar bagi peningkatan pendapatan bagi kelompok masyarakat berpendapatan rendah. Dalam pengembangan UMKM, langkah ini tidak semata-mata merupakan langkah yang harus diambil oleh Pemerintah dan hanya menjadi tanggung jawab Pemerintah. Pihak UMKM sendiri sebagai pihak internal yang dikembangkan, dapat mengayunkan langkah bersama-sama dengan Pemerintah. Karena potensi yang mereka miliki mampu menciptakan kreatifitas usaha dengan memanfaatkan fasilitas yang diberikan oleh pemerintah (Dwi, 2013).

Pemberdayaan Usaha Mikro Kecil Menengah atau yang sudah familier dengan sebutan UMKM ditengah tingginya persaingan dan arus era globalisasi memaksa pelaku UMKM harus mampu menyesuaiakan perubahan tersebut dan siap menghadapi tantangan global. Era globalisasi menuntut peningkatan inovasi produk dan jasa, pengembangan skill dari sumber daya manusia, pengembangan teknologi dan perluasan area pemasaran. Hal ini sangat penting dilakukan oleh pelaku UMKM agar dapat bersaing dengan produk luar negeri yang notabene sudah menguasai pasar di Indonesia. Hardjanto, 2014 (dalam Juvenal, 2015) mengemukakan bahwa di era globalisasi dengan persaingan di segala bidang, pemerintah dituntut untuk mengubah paradigma orientasi global. Perkembangan UMKM masih banyak mengalami kendala yang berdampak lemahnya daya saing terhadap produk impor. Kendala yang umum dihadapi oleh pelaku UMKM adalah terbatasnya akses permodalan, penggunaan teknologi masih kurang, serta rendahnya tingkat pengetahuan dan ketrampilan dari SDM yang ada. Selain itu juga perencanaan yang kurang matang serta tujuan dari kegiatan usaha yang kurang jelas mengakibatkan lemahnya daya saing UMKM terhadap produk impor maupun perusahaan bermodal besar. Eksistensi UMKM seharusnya tidak diragukan lagi, mengingat sektor UMKM ini banyak menyerap tenaga kerja yang terbukti mampu bertahan ditengah-tengah badai krisis ekonomi dan menjadi roda penggerak ekonomi. Kurang berhasilnya pola pembangunan ekonomi yang berpijak pada perusahaan besar mendorong para perencana ekonomi untuk beralih pada pembangunan ekonomi yang memberdayakan usaha mikro kecil dan menengah. UMKM merupakan kelompok pelaku ekonomi terbesar dalam perekonomian Indonesia dan terbukti menjadi katup pengaman perekonomian nasional dalam masa krisis, serta menjadi dinamisator pertumbuhan ekonomi pasca krisis ekonomi (Gunartin, 2017).

Jadi secara garis besar pengertian UMKM adalah suatu usaha ekonomo yang mampu berdiri sendiri tanpa bantuan pihak lain, didirikan oleh perorangan atau badan usaha yang tidak termasuk kedalam anak perusahaan atau bukan cabang perusahaan yang dimilki oleh perusahaan lain.

Seperti entitas bisnis pada umumnya UMKM juga perlu menyusun laporan keuangan yang sesuai dengan standar akuntansi keuangan. UMKM perlu menyusun laporan keuangan karena laporan tersebut 
berisi informasi yang dapat dimanfaatkan untuk pengembangan usaha UMKM. Laporan Keuangan adalah sebuah informasi yang mencerminkan keuangan entitas atau suatu organisasi yang dapat digunakan untuk menilai bagaimana kinerja entitas atau organisasi tersebut pada suatu periode tertentu. Periode akuntansi yang ada di Indonesia memiliki rentang waktu dan yang digunakan pada umumnya di laporan keuangan, periode waktu yang biasa digunakan untuk menyusun laporan keuangan adalah bulanan, triwulan, dan tahunan. Laporan keuangan pada dasarnya merupakan hasil proses pencatatan akuntansi yang digunakan untuk berkomunikasi antara data keuangan atau aktifitas keuangan suatu perusahaan dengan pihak yang berkpentingan dengan data atau aktivitas yang berhubungan dengan laporan keuagan (Harahap, 2014).

Pada dasarnya laporan keuangan memiliki fungsi sebagai "alat pengujian" dari pekerjaan dalam fungsi pembukuan, akan tetapi seiring dengan perkembangan jaman fungsi laporan keuangan merupakan sebagai dasar untuk menentukan atau melakukan penilaian atas laporan posisi keuangan suatu perusahaan. Laporan keuangan juga dapat digunakan untuk menilai kinerja atau mengukur kemampuan perusahaan dalam memenuhi kewajibannya baik dalam jangka pendek maupun jangka panjang. Laporan keuangan juga dapat untuk melihat bagaimana kelangsungan usaha suatu perusahaan di masa depan.

Menurut Radja Adri (2007) disusunya laporan keuangan bertujuan untuk imenyed akan sebuah informasi mengenai bagaimana posisiikeuangan perusahaan, kinerja perusahaan, dan bagaimana perubahan posisi keuangan suatu perusahaan sehingga dapat bermanfaat bagi para pengguna laporan keuangan dan para pemakai laporan keuangan untuk pengambilan keputusan. Laporan keuangan menyajikan tentang pertanggung jawaban manajemen terhadap laporan keuangan sehingga mereka dapat membuat keputusan ekonomi yang sesuai, misalnya keputusan untuk menahan atau menjual investasi ke perusahaan lain atau untuk mengambil keputusan yang mengangkat kembali informasi manajemen.

Menurut SAK EMKM (2016) menyatakan tujuan disusunnya laporan keuangan adalah untuk menyediakan informasi posisi keuangan dan kinerja suatu entitas yang bermanfaat bagi sejumlah besar para pengguna laporan keuangan dalam pengambilan keputusan ekonomi oleh siapun yang tidak terdapat dalam posisi yang dapat meminta laporan keuangann secara khusus untuk memenuhi kebutuhan laporan keuangan.

Menurut Radja Adri (2007) dalam bukunya yang berjudul "Akuntansi Keuangan versi IFRS", menjelaskan tentang karateristik laporan keuangan. Ada empat karateristik kualitatif yang sesuai dengan SAK yang merupakan ciri khas dalam pembuatan dan penyajian laporan keuangan yang berguna bagi pemakai lapora ikeuangan. Karateristik tersebutiadalah sebagai berikut : 1) dapat dipahami, andal, dan 3) dapatdibandingkan

Namun, pada umumnya keuangan tidak penting dan tidak perlu, serta membutuhkan waktu, kecermatan, dan biaya. Selain itu, seringkali para pelaku UMKM kesulitan dalam melakukan pencatatan terhadap apa yang terjadi kepada operasional usahanya. Kesulitan ini menyangkutiatas bagaimana penelitian dan hasil yang dicapai oleh setiap usaha yang dijalankan (Soni, 2010). Kebanyakan para pelaku UMKM hanya menghitung berapa besar harta yang dimiliki dan berapa besar uang kas yang dipegang saja, mereka tidak mengetahui bahwa pengertian harta lebih dari atau lebih luas dari sekedar uang kas (AnakiSuryo, 2006).

Oleh karena itu pada umumnya pencatatan laporan keuangan UMKM hanya dicatat berdasarkan kas keluar dan kas masuk saja tanpa mencatat aktifitas ekonomi yang lainnya. Dengan hanya mencatat kas keluar dan kas masuk, maka pemilik UMKM sudah dapat mengetahui berapa jumlah pendapatan dan jumlah pengeluaran yang digunakan selama operasional perusahaan. Pemilik UMKM sudah merasa cukup dengan informasi ini, sehingga para pelaku UMKM enggan atau tidak mau untuk melakukan aktivitas pencatatan atau penyusunan laporan keuangan. Para pelaku UMKM hanya mengandalkan ingatan untuk mengingat segala sesuatu yang berkaitan dengan kegiatan operasional usahanya.

Dalam memudahkan UMKM untuk menyusun laporan keuangan, maka Dewan Standar Akuntansi Keuangan (DSAK) dan Ikatan Akuntansi Indonesia (IAI) mengeluarkan standar akuntansi khusus yaitu Standar Akuntansi Keuangan Entitas Mikro Kecil dan Menengah (SAK EMKM) yang berlaku efektif sejak 01 Januari 2018. SAK EMKM ini merupakan standar akuntansi keuangan yang jauh lebih sedrhana dan mudah bila dibandingkan dengan Standar Akuntansi Keuangan Entitas Tanpa Akuntabilitas Publik (SAK ETAP). SAK EMKM ditunjukan untuk digunakan oleh entitas yang tida atau belum mampu memenuhi persyaratan penyusunan laporan keuangan yang diatur dalam SAK ETAP. Dengan diterbitkannya SAK EMKM diharapkan para pelaku UMKM dapat menyusun laporan keuangan sesuai standar akuntansi keuangan, sehingga EMKM dapat menyadiakan informasi Laporan Posisi Keuangan, Laporan Laba Rugi dan Catatan Atas Laporan Keuangan yang bermanfaat dan digunakan sejumlah para pemakai laporan keuangan dalam pengambilan keputusan.

Terdapat penelitian terdahulu terkait penerapan SAK ETAP dan SAK EMKM pada UMKM. Nanang (2007) dalam penelitiannya yang berjudul Penyusunan Laporan Keuangan Pada Usaha Mikro Kecil dan 
Menengah Berdasarkan SAK EMKM di Surabaya, menyatakan bahwa mitra UMKM belum memiliki pembukuan yang terstruktur dan terkodifikasi dalam laporan keuangan yang baik sesuai standar EMKM. Laries, dkk (2013), dalam penelitiannya yang berjudul Penerapan Standar Akuntansi Keuangan Entitas Tanpa Akuntabilitas Publik (SAK ETAP) Studi Kasus Cv. Citra Pandion Bernas, menyatakann bahwa telah menerapkan laporan keuangan berdasarkan SAK ETAP, namun belum sepenuhnya menerapkan dan masih banyak unsur yang belum terpenuhi dan sesuai dengan SAK ETAP yang berlaku yaitu pendapatan tidak dipisahkan berdasarkan antara pendapatan operasional dan penghasilan. Lebih lanjut, Tatik (2018), dalam penelitiannya yang berjudul Penerapan SAK EMKM Sebagai Dasar Penyusunan Laporan Keuangan UMKM Studi Kasus pada UD. Dua Putri Sholeha Probolinggo, menyatakan bahwa laporan keuangan yang di UD. Dua Putri Sholeha Probolinggo belum disusun sesuai dengan SAK EMKM. Laporan keuangan terbatas pada penyusunan laporan keuangan tertabatas atas transaksi-transaksi yang ada dalam entitas.

Seperti penelitian-penelitian terdahulu tersebut, penelitian ini juga akan membahas penerapan SAK EMKM pada salah satu UMKM yaitu UD. Karya Tangi Banyuwangi yang bergerak dalam bidang manufaktur (Pembuatan Tas dan Souvenir) yang terletak di Dusun Kampung Karya, Desa Kebaman, Kecamatan Srono, Kabupaten Banyuwangi. Pada awal berdirinya tahun 2012, UD. Karya Tangi Banyuwangi ini hanya focus pada produksi dan tidak melakukan pemasaran sendiri. Namun seiring dengan perkembangan bisnisnya, UD. Karya Tangi Banyuwangi juga melakukan pemasaran sendiri mulai akhir tahun 2013. Meskipun telah berdiri sejak tahun 2012, UD. Karya Tangi Banyuwangi ini belum mampu menyusun laporan keuangan sesuai standar yang berlaku karena keterbatasan sumber daya manusia yang memahami penyusunan laporan keuangan. UD. Karya Tangi Banyuwangi hanya mencatat pemasukan dan pengeluaran kas saja sehingga tidak dapat menyediakan informasi keuangan yang memadai. Hal ini mengakibatkan kegiatan operasional perusahaan tidak terkontrol secara baik. Oleh karena itu, maka peneliti akan melakukan penelitian dengan judul "IMPLEMENTASI SAK EMKM SEBAGAI DASAR PENYUSUNAN LAPORAN KEUANGAN UMKM (Studi Kasus UD. Karya Tangi Banyuwangi)”..

\section{Metode}

\section{Jenis Penelitian}

Jenis penelitian yang digunakan adalah penelitian deskriptif kualitatif. Data yang di peroleh oleh peneliti ini dengan cara kualitatif yaitu denganidataiprimer. Data primer disini merupakan data yang dihasilkan dengan cara wawancara atau interview dengan pemilik mitra UMKM secara langsung untuk memberikan keterangan tentang permasalahan yang menggambarkan suatu gejala atau kondisi perusahaannya berkaitan dengan permasalahan yang diajukan oleh peneliti.

\section{Metode Pengumpulan Data}

Untuk penelitiannya, cara mengumpulkan data oleh peneliti yaitu dengan cara sebagai berikut:

1. Wawancara

Menurut Sugiyono (2014) Wawancara merupakan proses untuk memperoleh data untuk penelitian dengan cara Tanya jawab dengan bertatap muka antara penanya dengan narasumber. Dalam penelitian ini, peneliti melakukan wawancara atau survey langsung ke subyek penelitian dengan cara memberikan pertanyaan langsung atau berbicara secara lisan dengan pemilik UMKM.

2. Pengamatan (Observation)

Obeservasi merupakan teknk pengumpulan data dengan cara pengamatan dan pencatatan langsung di lokasi penelitian. Observasi ini dilakukan langsung ke subyek dengan cara pengamatan dan pencatatan langsung di UD. Karya Tangi Banyuwangi.

3. Dokumentasi

Menurut Sugiyono (2014) Dokumentasi merupakan metode pencarian dan pengumpulan data mengenai catatan, buku-buku, majalah, laporan, dokumentasi dan sebagainya. Dalam penelitian ini, peneliti melakukan dokumentasi dari UD. Karya Tangi Banyuwangi yaitu berupa foto, laporan keuangan, profil perusahaan dan lain-lain.

\section{Sumber Data}

Menurut Arikunto (2002), Sumber data dibedakan menjadi dua yaitu data primer dan data sekunder, dimana sumber data ini adalah subyek yang dimana sebuah data yang dapat diperoleh secara langsung. Berdasarkan pengertian di atas maka dapat ditarik kesimpulan bahwa yang dimaksud dengan sumber data merupakan data dari penelitian yang akan digunakan untuk mendapatkan dan menggali sebuah informasi yang deperlukan untuk sebuah penelitian yang terkait. 


\section{Metode Analis isi Data}

Menurut Sugiyono (2014) Analisis data adalah sebuah proses mencari dan menyusun sebuah data secara sistematis data yang diperoleh dari hasil wawancara, catatan lapangan dan dokumentasi dengan cara mengorganisasikan semua data ke dalam sebuah kategori yang dapat menjabarkan ke dalam unitunit, melakukan sintesa, menyusun ke dalam pola dan memilih mana yang penting dan mana yang akan dipelajari dalam membuat sebuah kesimpulan sehingga dengan mudah dapat dipahami oleh diri sendiri maupun orang lain.

\section{Hasil dan pembahasan}

\section{Laporan Keuangan UD.Karya Tangi Banyuwangi Sebelum Diterapkan SAK EMKM}

UD. Karya Tangi Banyuwangi di dirikan sejak Desember 2012 dan usaha ini sudah berjalan selama 6 tahun. Dalam mengembangkan bisnisnya, pemilik UMKM mengalami banyak kendala dan permasalahan yang terjadi.

\section{Penyusunan Laporan Keuangan UD. Karya Tangi Banyuwangi BerdasarkaniSAKiEMKM}

Penerapan SAK EMKM pada laporan keuangan UD. Karya Tangi banyuwangi dimaksudkan agar pemilik UMKM mengetahui bagaimana langkah-langkah untuk menyajikan dan menyusun laporan keuangan seperti standar yang berlaku. Langkah yang harus dilakukan dalam mencatat laporan keuangan yaitu pengakuan dan pengukuran, kemudian melakukan pencatatan transaksi dan mengelompokkan akun-akun laporan keuangan, dan langkah selanjutnya adalah menyusun dan menyajikan laporan keuangan dengan menggunakan buku-buku pencatatan transaksi. Dalam SAK EMKM tidak ada laporan keuangan arus kas, karena di dalam SAK EMKM hanya terdapat 3 laporan keuangan adalah laporan posisi keuangan, laporann laba rugi dan catatan atas laporan keuangan.

\section{Simpulan dan saran}

Laporan keuangan yang disusun oleh UD. Karya Tangi Banyuwangi masih sangatlah sederhana dan simpel. Laporan keuangan UD. Karya Tangi Banyuwangi mencatat semua biaya yang dikeluarkan selama perusahaan beroperasi sampai saat ini, laporan yang telah disajikan meliputi laporan penjualan, laporan gaji karyawan, laporan pembelian bahan baku, laporan beban-beban, laporan perlengkapan dan laporan peralatan. Meskipun laporan keuangan yang disajikan oleh UD. Karya Tangi Banyuwangi sudah meliputi kegiatan usaha selama satu tahun, namun laporan keuangan yang disusun oleh UD. Karya Tangi Banyuwangi belum sesuai dengan laporan keuangan yang terdapat di SAK EMKM.

Berdasarkan dari hasil kesimpulan dan keterbatasan penelitian yang telah disajikan oleh peneliti, maka peniliti dapat disarankan sebagai berikuti: Bagi peneliti selanjutnya, disaran agar mendapatkan cakupan yang lebih luas dalam mencari informasi- informasi tambahan yang akan digunakan untuk untuk penelitian dan sebagai acuan dalam menyusun laporan keuangan yang lebih lanjut.

\section{Daftar Rujukan}

Al Haryono Yusuf. Universitas Gadjah Mada. 2011. Dasar dasar Akuntansi (Jilid 1). Edisi 7. Hak Cipta, Yogyakarta.

Anak Suryo. 2006. Akuntansi Untuk UKM. Metode Akuntansi Praktis dan Sederhana Untuk UKM. Media Pessindo, Yogyakarta.

Arikunto, S. 2002. Prosedur Penelitian, Suatu Pendekatan Praktek.selemba Empat. Jakarta.

Ariefiansyah, Ryan dan Miyosi Margi Utama. 2013. Membuat Laporan Keuangan Gampang. Dunia Cerdas. Jakarta.

Dwi Martani,dkk. 2012. Akuntansi Keuangan Menengah Berbasis PSAK (Buku 1). Selemba Empat, Jakarta.

Dwi, Feni. 2013. Pengembangan Usaha Mikro, Kecil, Dan Menengah (Umkm) Melalui Fasilitasi Pihak Eksternal Dan Potensi Internal (Studi Kasus Pada Kelompok Usaha "Emping Jagung” Di Kelurahan Pandanwangi Kecamatan Blimbing, Kota Malang) . Jurnal Administrasi Publik (JAP), Vol. 1, No. 6, Hal. 1286-1295 
Fahmi, Irham. 2012. Analisis Kinerja Keuangan. Alfabeta, Bandung.

Gunartin . 2017. Penguatan Umkm Sebagai Pilar Membangun Ekonomi Bangsa . Jurnal Pendidikan, Hukum dan Bisnis Vol.1 No. V Desember 2017

Harahap, Y.R. 2014. Kemampuan Menyusun Laporan Keuangan yang Dimiliki Pelaku UKM dan Pengaruhnya Terhadap Kinerja UKM. Jurnal Riset Akuntansi, Vol 14 No 1.

Nina, Ivana. 2018. Implementasi Sak Emkm (Entitas Mikro, Kecil Dan Menengah) Pada Umkm Borneo Food Truck Samarinda Community . Journal of Accounting and Business Management (RJABM) Volume 2 No.2 December 2018

Salmiah, Neneng. 2018. Pemahaman Pelaku Umkm Terhadap Sak Emkm : Survey Pada Umkm Yang Terdaftar Di Dinas Koperasi Dan Ukm . Jurnal Akuntansi Dewantara Vol. 2 No. 2 Oktober 2018

Surya, Raja Adri Satriawan. 2012. Akuntansi Keungan Versi IFRS. Yogyakarta Graha Ilmu. Edisi Pertama.

Tatik, SE, M. Ak, Ak, CA. 2018. Potensi Kepatuhan Pembayaran Pajak Pada Pelaku Umkm (Usaha Mikro Kecil Dan Menengah) Pasca Penerbitan Peraturan Pemerintah Nomor 23 TAHUN 2018 (Studi Kasus Pada UMKM di Kabupaten Sleman-Yogyakarta). Journal \& Proceding, FEB.UNSOED Universitas JENDERAL SOEDIRMAN, Vol 8 No 1. 